\title{
Amendments to California Corporation Laws, 1937: Readjusting Stock Structure
}

7 HE increased volume of refinancing which developed in 1935 and 1 1936, involving changes in the stock structure of corporations, focused the attention of counsel for corporations and investment bankers upon what appeared to be troublesome ambiguities in certain sections of the California General Corporation Law dealing with the amendment of articles of incorporation and the merger or consolidation of domestic and foreign corporations. The Committee of the State Bar on Revision of Corporation Laws not having been reappointed in 1937, certain lawyers who had been members of that Committee and who were acting on a similar committee of the Los Angeles Bar Association undertook the drafting of the desired amendments in conjunction with Professor Henry W. Ballantine and with representatives of the California Secretary of State.

The same refinancing transactions brought to a head certain questions as to the apphication of the Cahformia Corporate Securities Act to changes in outstanding stock resulting from amendments of articles of incorporation; and after considerable discussion with representatives of the Attorney General's office and the Corporation Commissioner, the latter drafted an amendment to the Corporate Securities Act intended to clarify the situation, which was enacted by the 1937 legislature. ${ }^{1}$ Similar problems arose in interpreting the Cahifornia Public Utilities Act, as apphed to the issuance of refunding securities by public utilities. These were sought to be answered by appropriate amendments of the Public Utilities Act, drafted and enacted with the approval of the State Railroad Commission. ${ }^{2}$

\section{WHEN CLASS VOTE REQUIRED TO CHANGE SHARES}

Probably the most important change in the General Corporation Law in 1937 was the amendment of Section $362 \mathrm{a}^{3}$ of the Civil Code. The primary purpose of the amendment was to define the situations in which a vote of stockholders by classes is required for the adoption of amendments of articles of mcorporation changing outstanding shares.

Since 1929 the law has reqnired, for the adoption of an amendment to articles of incorporation, the approval of the holders of a majority of the outstanding sliares of a corporation, with the additional require-

1 Cal. Stats. 1937, c. 833, effective August 27, 1937.

2 Cal. Stats. 1937, c. 249, effective August 27, 1937.

3 Cal. Stats. 1937, c. 676, effective August 27, 1937. 
ment of the approval of the holders of two-thirds of the shares of each class outstanding in cases in which the amendment would change the preferences or restrictions of any class of outstanding shares. ${ }^{4}$ The two principal objections to the section encountered in its apphication to a refinancing transaction were: first, the difficulty of determining whether or not a particular amendment would change the preferences or restrictions of outstanding shares; and second, the unreasonableness of requiring the approval of the holders of two-thirds of each of several classes of shares, which might clearly not be affected adversely by the proposed amendment.

To illustrate these objections, we may consider the case of a corporation having outstanding redeemable $7 \%$ preferred shares and common shares. The corporation may desire to take advantage of a favorable securities market which will enable it to sell an issue of $5 \%$ preferred shares, thus providing the funds with which to retire the outstanding $7 \%$ preferred shares. As the first step in the refinancing, it may be necessary to amend the articles of incorporation to create the new class of $5 \%$ preferred shares. Does the aniendment creating the new class of $5 \%$ preferred shares "change the preferences or restrictions" of the outstanding $7 \%$ preferred shares or the outstanding common shares? In order to market the new preferred shares, it may be necessary to make them rank on a parity with the outstanding $7 \%$ preferred shares as to distribution preferences, whether by way of dividends or on liquidation. If a change in the preferences or restrictions of outstanding shares is interpreted to mean merely a direct change in the statement of the preferences or restrictions applicable to those shares as set forth in the articles, one might conclude that the introduction of a new class of preferred shares into the authorized capital structure of the corporation would not involve any change in the preferences or restrictions of either the outstanding $7 \%$ preferred shares or the outstanding common shares. If, however, the phrase "change the preferences or restrictions of outstanding shares" is given a broader interpretation to include an indirect change in the rights of the outstanding $7 \%$ preferred shares, resulting from the creation of a new class of $5 \%$ preferred shares having the same priority in distribution preferences, or an indirect change in the preferences or restrictions of the common shares resulting from the authorization of the new class of preferred shares, then the amendment of the articles creating the new stock must be approved by the holders of twothirds of each of the classes of outstanding stock.

4 Former CAL. Crv. CODE $\S 362$, Cal. Stats. 1929, pp. 1261, 1275-1277, effective August 14, 1929; former CaL. Crv. Code $\$ 362$ a, Cal. Stats. 1933, pp. 1358, 13941395, effective August 21, 1933. 
In the absence of judicial interpretation, the underwriters' counsel, proverbially cautious, will insist on the safer procedure and require the corporation to obtain the consent of the holders of at least two-thirds of each class of outstanding shares. In the case of large corporations with thousands of stockholders, the practical difficulties of obtaining such a high percentage of consent present a real obstacle to the refinancing, particularly as such a transaction is dependent upon a favorable market for the absorption of the new issue and must therefore be consummated as promptly as possible. Furthermore, considering that the outstanding $7 \%$ preferred shares are redeemable at the option of the corporation, usually at a premium, and that the corporation in redeeming such shares is merely exercising a right for what is believed to be the best interests of the corporate enterprise as a whole, it may be deemed beyond the purview of sound policy to require the consent of the holders of two-thirds of the outstanding preferred shares to such an amendment. The wisdom of such a requirement is particularly doubtful when one appreciates that such an interpretation places in the hands of a minority of one class of shares, viz., $34 \%$ of the outstanding $7 \%$ preferred shares, the power to defeat a refinancing operation which would appear to be advantageous to the corporation. From a broader viewpoint, such an interpretation would seein to be inconsistent with the policy expressed in other sections of the General Corporation Law which permit the mortgaging of the corporate assets merely by authority of the board of directors without any specific approval of shareholders, ${ }^{5}$ and which permit the sale of all of the corporate assets with the consent of shareholders holding merely a majority of the voting power. ${ }^{6}$

The basic problem illustrated in the example discussed above might appear in various phases in a number of different transactions, of which the mention of a few will be sufficient to indicate its general importance. A corporation with only one class of shares authorized and outstanding wishes to raise additional capital through the issuance of preferred shares. Will the amendment of the articles creating the class of preferred shares change the preferences or restrictions of the outstanding shares and therefore require the consent of the holders of two-thirds of the outstanding shares? A corporation with outstanding first preferred shares, second preferred shares and common shares desires to create a new class of third preferred shares. Does the amendment creating the new class of third preferred shares change the preferences or restrictions of the common shares? If it does, then not only will the consent of the holders of two-thirds of the common shares be required, but also the consent of

5 Car. Civ. Code $\$ 344$.

${ }^{6}$ Cat. Ctv. Code $\$ 343$. 
the holders of two-thirds of each of the preferred classes, although the new class is to be merely junior to those classes. A corporation has outstanding preferred and common shares; it proposes to amend its articles to increase the authorized number of preferred shares. Does such an amendment change the preferences or restrictions of either the outstanding preferred or common shares? If it does, the consent of the holders of two-thirds of each class will be required. A corporation has outstanding only one class of shares; it is proposed to amend its articles to increase the authorized number of shares of this one class. Is the originally authorized number of shares of this class a restriction pertaining to this class? If it is, then the consent of the holders of two-thirds of this class will be required merely to increase the authorized number of its shares.

In endeavoring to solve these problems, the draftsmen of the 1937 amendments naturally turned to the corporation laws of other jurisdictions to ascertain their manner of meeting the question. None of the statutes investigated offered any solution, it being common practice, where any class vote at all is required for the amendment of the articles, to require a specified percentage (whether a bare majority or more) and to require a class vote only in cases in which that class would be "adversely affected" by the proposed amendment. ${ }^{7}$ It was felt that the phrase "adversely affected" is subject to almost as great difficulty of interpretation and application as the phrase "change the preferences or restrictions." They therefore attempted to redraft Section 362a to specify the particular types of amendment which would require a class vote, retaining for amendments felt clearly to be adverse to a particular class the requirement of the approval of two-thirds of that class, while at the same time for the sake of clarity specifying also particular types of amendments which would not require a class vote. It was recognized that such a course would be fraught with the dangers inherent in any effort to specify and categorize the various respects in which articles may be amended. Despite these dangers, however, which could be minimized by as careful drafting as possible, it was felt that such a pattern would be preferable to a continuation of the uncertainties involved in the interpretation of such phrases as "change the preferences and restrictions" and "adversely affected."

Specifically, Section 362a as amended in 1937 retains the former provisions as to amendment of articles by incorporators prior to the issuance of stock or the taking of subscriptions therefor, and the requirement, as

7 Delaware General Corporation Law, § 26, Des. REv. CoDE (1935) § 2058; Nevada General Corporation Law of 1925, § 7, Nev. Cosrp. Laws (Hillyer, 1929) § 1606; Minnesota Business Corporation Act, $\$ 38$, Minn. STat. (Mason, 1927) $\S 7472$. For further examples see Hills, Model Corporation Act (1935) 48 HARv. L. REv. 1334, 1380, n. 97. 
to amendments generally, of the approval by vote or consent of the holders of a majority of the voting power. If, however, the amendment will change any outstanding shares so as to (a) make them assessable, (b) reduce their dividend rate, (c) make them non-cumulative as to dividends, (d) reduce their redemption price, (e) reduce their liquidation preference, (f) reduce their conversion rights, (g) reduce their voting rights, $(h)$ reduce their options or rights to purchase other shares, (i) reduce their sinking fund requirements, or $(j)$ make shares "subject to the preferences of other then ${ }^{8}$ outstanding shares," then in any such case the shareholder approval required must include the approval of the loolders of two-thirds of the outstanding shares of any class so changed by the amendment. ${ }^{9}$

It should be pointed out that this enumeration in Section 362a (3) was not intended to increase the scope of the authorized purposes of the amending power as already specified in Section 362 (7), but merely to clarify the instances in which a two-thirds class vote is required. The power of amending the articles of incorporation, hike all other corporate powers, must be exercised by the directors or by the shareholders or both, as the case may be, only in good faith, for the common good and with due regard for the interests of all classes of shareholders, and must not be abused for the advantage of some one group. ${ }^{10}$ Furthermore, there may be doubts on constitutional grounds as to whether or not an amendment of the articles can effectively divest shareholders of a right which las become vested, such as the right to theretofore accumulated dividends, as

8 In the Deering 1937 California Civil Code $\$ 362 a(3)$ (j), the words "then outstanding" were by error printed "than outstanding."

9 It was thought preferable not to provide that arrearages of accumulated and unpaid dividends may be scaled down by amendment of the articles, because difficult questions of constitutionality are raised by such a provision. The vested rights of the non-consenting stockholders in such dividends would seem to be thereby impaired. Keller v. Wilson \& Co., Inc. (Del., 1936) 190 Atl. 115. Cf. In re Duer (1936) 270 N. Y. 343, 1 N. E. (2d) 457 ; Note (1937) 85 U. of PA. L. REv. 324. For discussion of this question see: Notes (1937) 35 MrcH. L. REv. 620; (1937) 4 U. OF CHr. L. REv. 645; (1937) 23 VA. L. REv. 579 ; (1937) 46 YALE L. J. 985; (1937) 46 YALE L. J. 1071. As to the equally delicate questions of making previously non-callable stock callable or of deferring a redemption date on which the corporation is obligated to redeem outstanding shares, see Breslav v. New York \& Queens Electric Light \& Power Co. (1936) 249 App. Div. 181, 291 N. Y. Supp. 932, aff'd (1937) 273 N. Y. 593, 7 N. E. (2d) 708; Note (1937) 46 YaLE L. J. 1055. Cf. Sutton v. Glove Knitting Works (1936) 276 Mich. 200, 267 N. W. 815, 105 A. L. R. 1447-52, holding that the legislature could not authorize the alteration of the redemption date under its reserved power.

10 Berle, Corporate Powers as Powers in Trust (1931) 44 Harv. L. Rev. 1049; Lattin, Equitable Limitations on Statutory or Charter Powers Given to Majority Stockholders (1932) 30 Mich. L. REv. 645, 663; 13 Fretceder, Cyclopedia of CoRgoRATIONS (Perm. ed. 1932) $\$ \S 5810,5811$. 
distinguished from rights which may thereafter accrue, such as the right to have dividends cumulative in the future. ${ }^{11}$

If, however, an amendment will change any outstanding shares beneficially in any one or more of the ways specified in Section 362a (4), such as to make them nonassessable, to increase their dividend rate, or to make them cumulative as to dividends, etc., then the shareholder approval required must include the approval of the holders of a majority of all other outstanding shares of the corporation. ${ }^{12}$

Section 362a (5) now further provides that for the creation of a new class or series of shares not theretofore authorized by the articles, or for the increase of the authorized number of shares of any existing class or series, the approval of the holders of a majority of all outstanding shares, whether voting or nonvoting, shall be requisite and sufficient.

The amended section retains the former requirement of unanimous stockholder approval of an amendment making the shareholders personally liable for assessments levied on the shares, and the requirement (intended to protect cumulative voting rights) that any amendment reducing the authorized number of directors below five nust be approved by the holders of more than eighty per cent of the outstanding voting shares. It is also still provided that different series or subdivisions of a class shall not be deemed to be different classes for the purpose of the class votes required, unless a particular series would be adversely affected by an amendment in a different manner than other shares of the same class.

A troublesome question as to the validity of provisions of articles requiring a higher percentage of class vote than the statutory percentage has been eliminated by an express provision in the section that articles of incorporation may include requirements of higher percentages of stockholder approval for particular amendments than those required by the statute.

It is also made clear that the special requirements of the section as to stockholder approval for various types of amendments do not apply to an amendment the sole purpose of which is to increase or decrease the number of outstanding shares (such an increase being commonly referred to as a stock spht-up) without changing the rights or preferences of the holders of shares so affected, provided the articles as amended contain a statement of the pnrpose and the effect of the amendinent on outstanding shares.

A new provision has been inserted for the purpose of more adequately informing stockholders, requiring that in the solicitation of proxies for the purpose of voting on any amendment of the articles which would change

11 Ballantine, California Corporation Laws (1932) 13, 14.

12 CAL. Crv. CODE $\S 362 a(4)$. 
the rights of outstanding shares in any one or more of the specified respects above referred to, the corporation shall mail to each stockholder a concise summary of the proposed amendment and the changes in stockholders' rights proposed to be effected thereby. ${ }^{13}$ The performance of this requirement, however, is expressly not made a condition precedent to the validity of the amendment. However, we may assume that any stockholder opposed to a proposed amendment, who found that the management was not complying with this requirement could enforce it by appropriate legal proceedings.

\section{READOPTION AND RESTORATION OF PROVISIONS OF THE ARTICLE}

The amended section 362a (8) now specifically authorizes the readoption and restoration of any provision of the original articles superseded or changed by any certificate pursuant to any statute which did not expressly provide that such certificate amended the articles (as under section 362 (11)), with the appropriate himitation that if the effect of such restoration or readoption would be the same as to outstanding shares as an amendment of the type specified in the amended section $362 \mathrm{a}$ as requiring a particular percentage of stockholder approval, the restoration or readoption must receive the same approval as would be required for that type of amendment. ${ }^{14}$

\section{PURPOSES OF AMIENDMENT OF ARTICLES}

Civil Code section 362 sets forth the purposes for which the articles can be amended, including changes in the terms and preferences of issued shares. Section 290 of the Civil Code specifies certain matters which must or may be contained in the original articles of incorporation. Since there is no reason why a corporation should not be permitted to amend its articles to set forth anything which would have been proper in the original articles, it is evident that the language of these two sections should substantially conform. In 1933 subdivision (5) of Section 290 was amended to include conversion rights and voting rights among other matters which might be left for future determination by the board of directors with respect to particular classes or series of authorized shares, at any time prior to the actual issuance of such shares. ${ }^{15}$ The corresponding subdivision, being subdivision (8), of Section 362 was not similarly amended in 1933. The result was that subsequent to 1933, although the original articles of a corporation might leave these matters to be deter-

13 This provision was suggested in Note, Corporate Recapitalization by Charter Amendment (1937) 46 YaLE L. J. 985.

14 See Pratt-Low Preserving Co. v. Jordan (1933) 217 Cal. 282, 18 P. (2d) 676.

15 Cal. Stats. 1933, pp. 1358-1361. 
mined by directorate action prior to the issuance of the shares, similar authority could not be conferred upon the directors by an amendment of the articles unless under the general authority in section 362, subdivision 12. ${ }^{16}$ The sole purpose of the amendment of Section 362 in 1937 was to conform it in these and other minor respects to the language of Section 290 as amended in 1933.

\section{REDEMIPTION PROCEDURE}

The subject matter of Civil Code section $347^{17}$ is new to the General Corporation Law. It specifies the procedure which may be followed by a corporation in redeeming outstanding shares which by the terms of the articles are redeemable at the option of the corporation. The reason for its inclusion is that the articles of incorporation of many corporations with outstanding redeemable preferred stock are woefully inadequate in setting forth the steps to be taken by the corporation in exercising its redemption rights. Particularly in a refinancing transaction such as those heretofore discussed which have been common in the last two years, it is extremely important to know definitely that the outstanding preferred shares proposed to be redeemed have been effectively redeemed and to know exactly at what point the redenption is effective. If the articles of incorporation merely state that the preferred stock may be redeemed at the option of the corporation at a specified price, but do not provide the mechanics of redemption nor state at what point the stock is redeemed, the result may be to place substantial legal and practical obstacles in the way of a beneficial refinancing which has for its object the redemption of the outstanding preferred stock. In the case of many corporations, particularly those with a large number of stockholders, it is not a sufficient answer from the practical standpoimt to say that the articles of incorporation may be amended to set forth the redemption procedure with greater particularity.

For such corporations the amendment procedure is itself expensive and often cannot be accomphished within the necessary time limit. To assist corporations in such a position therefore, it was thought desirable to provide by statute a redemption procedure which could be followed with certainty, subject of course to any requirements of the articles. The new Section 347 therefore may be fairly regarded as purely procedural rather than substantive. It provides, in brief, that subject to the provisions of the articles, any corporation with outstanding redeemable shares may effect the redemption by causing notice of the redemption to be published for at least two weeks, and that it shall be the duty of the corporation to mail a copy of the redemption notice to each holder of record

10 Cal. Stats. 1937, c. 678, effective August 27, 1937.

17 Cal. Stats. 1937, c. 678, effective August 27, 1937. 
of the shares to be redeemed not more than sixty, nor less than twenty, days before the redemption date, and that if on or prior to the redemption date the corporation shall deposit with a bank or trust company as a trust fund, for the account of the holders of the called shares, a sum sufficient to redeem such shares, the shares so called shall be deemed to have been redeemed on the redemption date.

\section{MERGER OR CONSOLIDATION OF DOMESTIC AND FOREIGN CORPORATIONS}

Most modern corporation laws provide for the merger or consolidation of a domestic corporation with one or more corporations organized under the laws of other states, provided that the laws of such other states also permit such a merger or consolidation. The California General Corporation Law, as enacted in 1931, contained in Section 361a autlority for such a "mixed" merger or consolidation. In succeeding years, however, both the Secretary of State's office and practicing lawyers have found the section to have been ambiguous in a number of instances, none of which is substantial from the viewpoint of policy but all of which proved to be productive of unanswerable questions of interpretation and resulting uncertainty and delay. Without going into a detailed discussion of these questions, it may suffice to say that practically the entire section has been redrafted, with the approval and cooperation of the Secretary of State's office, in a manner which it is believed affords the stockholders of a Califorma corporation involved in such a mixed merger or consolidation the same rights and protection which they would have in case of a merger or consolidation with another California corporation, yet whicl nevertheless has clarified the statutory language and procedure in a desirable manner. ${ }^{18}$

\section{PERMITS FOR CHANGES OF PREFERENCES IN OUTSTANDING SHARTS UNDER THE CORPORATE SECURITIES ACT}

The California Corporate Securities Act requires a corporation to obtain from the Corporation Commissioner a permit to sell securities of its own issue. ${ }^{19}$ The word "security" is broadly defined. ${ }^{20}$ The term "sale" or "sell" is likewise broadly defined to include every disposition or attempt to dispose of a security or interest in a security for value and embraces a contract of sale and an exchange. 21 The General Corporation Law authorizes a corporation, by amendment of its articles, to change the preferences, rights, or restrictions of outstanding shares and provides that the amendment shall become effective upon filing an appropriate certifi-

\footnotetext{
18 Cal. Stats. 1937, c. 583, effective August 27, 1937.

19 Corporate Securities Act \&3, 2 CaL. GeN. Laws (Deering, 1932) 1924.

20 Corporate Securities Act, supra, \& 2 (7).

21 Corporate Securities Act, supra, \$2 (8).
} 
cate of amendment in the office of the Secretary of State. ${ }^{22}$ A question which has troubled practicing lawyers, the Corporation Commissioner and the Attorney General is whether or not any sale of securities requiring a permit from the Corporation Commissioner is involved when a corporation amends its articles to change the preferences of outstanding shares or to create a new class of shares.

For example, suppose a corporation with outstanding $7 \%$ preferred shares and outstanding common shares amends its articles of incorporation in accordance with the General Corporation Law to change the dividend rate on the outstanding preferred shares from $7 \%$ to $5 \%$. Has the corporation thereby in effect issued new $5 \%$ preferred shares in exchange for the outstanding $7 \%$ preferred shares? Has the amendment likewise changed the outstanding common shares to such an extent that the common shares outstanding after the amendment can be deemed to be different shares from those outstanding before the amendment? If so, it would seem that an exchange of old common shares for new common shares has resulted from the amendment. In such a case it is possible that the corporation will not issue any new stock certificates whatsoever and thus may not go through any of the physical motions of issuing a security. Under the General Corporation Law the amendment reducing the dividend rate is effective upon the filing of the certificate of amendment in the office of the Secretary of State. ${ }^{23}$ Can this clear provision of the General Corporation Law be properly nullified or conditioned by construing the General Corporation Law, together with the Corporation Securities Act, in such a manner as to conclude that the amendment of the articles is not effective unless a permit from the Corporation Commissioner has been obtained? If a sale of securities is involved in such an amendment merely by virtue of the amendment proceeding itself, at what point can it be said that the sale is made? Is it when a shareholder gives his consent to the amendment of the articles? Is it when the percentage of shareholders' consents required by the General Corporation Law to make the amendment effective has been obtained? Is it not until the certificate of amendment has been filed in the office of the Secretary of State? Or is it only when the corporation issues a new stock certificate containing a statenient of changed preferences upon surrender of the outstanding stock certificate containing a statement of the old preferences?

So far as the writer knows these questions have not been answered by judicial decision in California. In the absence of judicial decision the Corporation Commissioner is bound to follow the opinion of the California Attorney General. The opimions of the Attorney General on these

22 CAI. CTV. CODE $\$ \S 362,362 b$.

23 Caz. Civ. Code $\$ 362 \mathrm{~b}$. 
questions prior to 1936 were not altogether consistent. The result was that a definite stand could not be taken by the Corporation Commissioner. In 1936, however, the Attorney General concluded that any amendment of the articles involving substantial changes in the rights or preferences of outstanding shares involved, as a matter of law, the sale of the outstanding securities as changed by the amendment in exchange for the outstanding securities as they existed prior to the amendment, and that a permit from the Corporation Commissioner in such instances is required. ${ }^{24} \mathrm{It}$ is the writer's personal view that the opinion of the Attorney General is unsupportable as sound statutory construction and this view is shared by a large number of California lawyers specializing in corporation practice. There are undoubtedly nany corporations which in the past have amended their articles of incorporation to change the preferences of outstanding shares or to create new classes of shares, in reliance upon the exclusive applicability of the corporation law without obtaining a permit from the Corporation Conmissioner. A decision of the courts conforming to the opinion of the Attorney General would probably invalidate the amendments of millions of dollars worth of outstanding shares.

Be that as it nuay, the Corporation Conmissioner must follow the opinion of the Attorney General, and some idea of the practical effect can be gained from an actual experience of the writer in the fall of 1936. A Delaware corporation, doing its principal business in California and having outstanding preferred shares of several series, as well as outstanding common shares, desired to amend its charter to create a new class of preferred shares which were to be offered for sale in Cahiforma and the proceeds used in part to retire an outstanding series of preferred shares. The corporation conipleted its charter aniendnent proceedings in accordance with the laws of Delaware, and, in the light of the generally recognized principle that a state cannot interfere with the internal affairs of

24 Opinion No. 8385 (December 20,1932) was based on the proposal of a Delaware corporation, with Class $A$ and Class $B$ sbares autborized and outstanding, to ainend its charter to authorize only one class of sbares and to divide the one class of shares so authorized between the holders of the Class A and Class B sbares in exchange therefor on a basis which involved a smaller number of the new shares to the holders of the Class B shares. The Attorney General concluded that a permit would be required for the issuance of the new shares, distinguishing Opinion No. 7166 (June 26, 1930).

Upon the proposal of a corporation with two million shares of the par valuo of $\$ 10.00$ each authorized and outstanding, to amend its charter to decrease its authorized capital to two thousand shares of the par value of $\$ 1.00$ each, and to exchange one of the new shares for each one thousand of the old shares, tbe Attorney General concluded in Opinion No. 8486 (March 7, 1933) that a permit would be required since the transaction involved a substantial reduction of capital and the resulting elimination of a capital deficit which would leave the rights of the shareholders substantially changed. 
foreign corporations, ${ }^{2 \pi}$ it would seem clear that the charter amendment had become effective under the Delaware law, and that the new class of preferred shares had consequently been duly authorized and created by the amended charter.

The corporation then applied to the California Corporation Commissioner for a permit to issue the new preferred shares. The Corporation Commissioner, acting on the opinion of the Attorney General, refused to grant a pennit for the issuance of the new shares unless the corporation also applied for a permit to "reissue" the outstanding preferred and comnon shares, the theory being apparently that the charter amendment creating the new class of preferred shares had so changed the outstanding preferred and common shares as to make them different securities than they were before, and that a permit for their reissuance would be required under the California Corporate Securities Act. The untenability of the Attorney General's opinion applied to these facts would seem too obvious to require elaboration. It was conceded, of course, that the corporation did require a permit from the Corporation Commissioner to issue the new class of preferred shares, but the Commissioner refused to grant such permit unless the corporation also apphed for a permit to reissue the outstanding preferred and common sliares. The corporation, therefore, had no practical alternative except to make the apphication and pay a filing fee of several hundred dollars for a permit authorizing it to reissue several million dollars par value of preferred and common shares already outstanding. To test the question in the courts by mandamus or other available proceeding would have involved considerable expense and a delay which would have made the marketing of the new preferred shares impossible.

As a result of this and other similar cases the matter was thoroughly discussed by interested counsel and representatives of the Attorney General and the Corporation Commissioner with a view to clarifying the situation, if possible, by appropriate legislation. It was found that regardless

In Opinion No. 10995 (October 20,1936) it appeared that a corporation with one class of shares authorized and outstanding amended its articles to reclassify its sharés as preferred and common, proposing to issue one share of preferred and one share of coinmon for each share theretofore outstanding. The issuance of the preferred was referred to as a "stock dividend." The Attorney General ruled that a permit was required for the issuance of both the new preferred and the new common, even though the quantum of interest of the shareholders would not be changed as a result of the transaction. The reasoning was that the different rights attaching to the new preferred and new common constituted the exchange of the old shares for these shares an exchange for value.

25 Southern Sierras Power Co. v. Railroad Comm. (1928) 205 Cal. 479, 271 Pac. 747; Dunham v. Chemical Bank \& Trust Co. (Okla., 1937) 71 P. (2d) $468 ; 2$ Beare, Conflict of Laws (1935) 885; 17 Fietcher, Cyclopedia of Corporations (Perm. ed. 1933) § 8425 . 
of the difficulties of legal interpretation, both the Attorney General and Corporation Commissioner were convinced that as a matter of policy stockholders and the investing public should be protected against substantial amendments of articles of incorporation foisted upon them by an unscrupulous management, by entrenching the alleged jurisdiction of the Commissioner over such amendments. Both officials were willing to concede, however, that there was something unfair about forcing a corporation which had already paid the statutory fee for a permit to issue its outstanding shares to pay a second fee for reissuing those same shares as changed by an amendment of the articles.

The final solution was an amendment ${ }^{26}$ to Section 26 of the Corporate Securities Act prescribing the filing fees for applications to the Corporation Commissioner, adding a new subsection 12 fixing a fee of $\$ 25$ for filing any application for permit to issue securities evidencing changed preferences of outstanding securities in excliange for such outstanding securities theretofore issued, after any change in the stock structure by an amendment to the articles, if the amendment has 'the effect of changing the number of or the preferences of the securities or changing or ehminating the par value. It is expressly provided, however, that no permit is required where the amendment only increases or decreases the number of shares authorized but unissued pursuant to tlie articles. This solution is helpful in reducing to a nominal degree the financial burden involved in following the Attorney General's opinion and it may be supposed resolves for the future the primary question as to whether or not a permit is required in such instances, since the statutory statement of the prescribed filing fee for such an application necessarily implies that a permit is required in such instances. It remains to be seen whether or not the amendment will be interpreted by the courts to constitute an indication of the legislative intent that a permit has heretofore been required in these cases. One also notes that the amendment leaves to the individual practitioner the determination of the difficult question as to the point at which the issuance of the changed securities occurs and, therefore, at what point in the amendment proceeding a permit should be obtained. Since the granting of a permit after the securities have been issued cannot be held to have validated the previous issuance without a permit, it would seem that the cautious practice would be to obtain the permit before the filing of the certificate of amendment or other document which, under the applicable corporation law, nuakes the amendment effective.

26 Cal. Stats. 1937, c. 833, effective August 27, 1937. 


\section{AUTHORIZED PURPOSES FOR ISSUE OF SECURITIES}

UNDER THE PUBLIC UTILITIES ACT

Section 52 of the California Public Utilities Act as in effect prior to 1937 histed as the only purpose for which a utility might issue its securities (a) the acquisition of properties, (b) the construction, completion, extension or improvement of its facilities, (c) the improvement or nxaintenance of its service, (d) the discliarge or lawful refunding of its obligations, and (e) the reimbursement of moneys (other than moneys received from the issuance of securities) actually expended for any of said purposes, except maintenance of service and replacements. ${ }^{27}$ Refinancing and reorganization of utilities during the past few years have raised such questions as: Can a utility offer to issue to its stockholders one class of stock in exchange for another? Can new stock be issued for tle purpose of redeeming outstanding preferred stock? Can the surviving utility in a nierger issue its securities in excliange for the outstanding stock of the other constituent utilities?

These questions may now be answered in the affirmative, as a result of the 1937 amendments to Section 52 of the Act adding to the authorized purposes for which a utility may issue securities; (a) for the reorganization or readjustment of its indebtedness or capitalization upon a merger, consolidation or other reorganization, and (b) for the retirement of or in exchange for outstanding securities. ${ }^{28}$

The aniended section also includes express authorization for the issuance of bonds and preferred stock bearing warrants entitling the holders to purchase common stock, and for the issuance of bonds and preferred stock convertible into common stock.

The Federal Securities Act exempts from its registration provisions securities issued in excliange for outstanding securities claims or property interests, or partly in sucl exchange and partly for cash, if the terms of the exchange have been approved, after a hearing upon their fairness, by any court, state or federal official or agency, or other governmental authority expressly authorized by law to grant sucl approval. ${ }^{29}$ In states such as Califorma whose laws require authorization from a state official or agency for the issuance of practically all securities, it would seem desirable and certainly not contrary to the policy of either the state or federal laws to avoid, wherever possible, duplication of expense involved in complying with the laws of both jurisdictions. Although it may not

272 Car. Gen. Laws (Deering, 1932) 3522.

28 Cal. Stats. 1937, c. 249, effective August 27, 1937.

29 Securities Act of 1933, as amended, $\$ 3$ (10), 15 U. S. C. A. (1936 Supp.) $\S 77$ c. See Note (1935) 23 CaLIF. L. REv. 348. 
.have seemed doubtful that the Califorma Railroad Commission had the authority referred to in the Federal Act, any possible doubt has been eliminated by including in the 1937 amendments to Section 52 of the Public Utility Act a provision expressly granting such authority to the Commission in language substantially identical with that used in the Federal Act.

Graham L. Sterling, Jr.

LOS ANGELES, CALIFORNIA 